\title{
FORECASTING OF VOLATILITY IN STOCK EXCHANGE MARKETS BY MS-GARCH APPROACH: AN APPLICATION OF BORSA ISTANBUL
}

\section{MS-GARCH Yaklaşımıyla Menkul Kıymet Piyasalarında Volatilite Tahmini: Borsa İstanbul Uygulaması}

\section{Abdulkadir KAYA* \& İkram Yusuf YARBAȘI}

\begin{abstract}
The volatility observed in securities markets has an important influence on the decision making processes of stock market stakeholders. In this study, the

Keywords: Volatility, Financial Risk, Markov Switching, BIST

JEL Codes: C58, E42, G32 volatilities in BIST100 index which represents Borsa Istanbul was analyzed. For this purpose, BIST100 index closing data for the period of 03.01.198820.04.2018 was used in the study. The BIST100 index was analyzed by Markov regime switching GARCH (MS-GARCH) with three regimes, standard, high and low volatility regimes. As a result of the triple regime MSGARCH intensive analysis, the existence of endogenous regimens was determined, in which the regime coefficients considered for the index were statistically significant. When the possibilities of regime transitions are analyzed, it is determined that the probability of continuing the standard volatility regime is 0.62 , the probability of transition to low volatility regime is 0.23 and the probability of transition to high volatility regime is 0.145 . Moreover, it was determined that the possibilities of regime passage in 5 and 20 days are very close to each other.
\end{abstract}

Anahtar Kelimeler: Oynaklık, Finansal Risk, Markov Değişim, BIST

JEL Kodları: C58, E42, G32

\section{Özet}

Menkul kıymet piyasalarında gözlemlenen volatiliteler, borsa paydaşlarının karar alma süreçlerini etkileyen önemli bir etkendir. Bu çalışmada Borsa İstanbul'u temsil eden BIST100 endeksinde oluşan volatiliteler analiz edilmiştir. Bu amaçla, çalışmada, 01.04.1993-20.04.2018 dönemi BIST100 endeksi kapanış verileri kullanılmıştır. BIST100 endeksi standart, yükssek ve düşük volatilite rejimleri olmak üzere üç rejime dönüştürülerek, Markov Rejim Değișim GARCH (MS-GARCH) ile analiz edilmiştir. Üçlü rejimli MSGARCH modeli ile yapılan analiz sonucunda endeks için ele alınan rejim katsayılarının istatistiksel olarak anlamlı olduğu, endekste rejimlerin varlığı tespit edilmiştir. Rejim geçişleri olasılıkları incelendiğinde ise birer günlük süreçte standart oynaklık rejiminin sürme olasılığı 0,62 , düşük volatilite rejimine geçiş olasılığ 0,23 ve yüksek volatilite rejimine geçiş olasılığının ise 0,145 olduğu belirlenmiştir. Ayrıca 5 ve 20 günlük süreçte rejim geçişlerinin olasılıklarının birbirine çok yakın olduğu tespit edilmiştir.

\footnotetext{
* Doç. Dr., Erzurum Teknik Üniversitesi, İktisadi ve İdari Bilimler Fakültesi, İşletme Bölümü, akadirkaya@erzurum.edu.tr, ORCID: 0000-0001-7789-5461

** Dr. Öğr. Üyesi, Erzurum Teknik Üniversitesi, İktisadi ve İdari Bilimler Fakültesi, Ekonometri Bölümü, ikram.yarbasi@erzurum.edu.tr, ORCID: 0000-0003-4689-5121
}

Makale Geliş Tarihi (Received Date): 21.05.2020 Makale Kabul Tarihi (Accepted Date): 06.04.2021 


\section{Introduction}

Modeling and predicting volatility in financial markets plays an important role in economic performance and financial stability. In particular, determining conditional volatility is seen as an important tool for setting risk measures (Ardia, 2008). The emergence of volatility models as an important risk assessment tool in financial markets has increased the interest in these models.

The concept of risk that people face in many areas of daily life can be expressed as the difference between expectations and realizations in financial markets. Risk, which has a significant impact on investor decisions, makes an important contribution to investors' alternative among the choices they will make for the future. Investors will try to generate income from their investments by taking the necessary financial measures against the risks that may occur in the future due to their investments in the financial markets and by reducing the costs that may arise. For this reason, it is inevitable to use risk management techniques and tools to measure and control the risks that may arise for the related investments. Increasing the ability of investors to manage risk will increase the appetite for accepting the risks underlying the desire to earn income and for making decisions for the future and this will also contribute to the development of financial markets. At this point, it can be stated that regime switching models and Bayesian prediction techniques are among the current methods in terms of risk assessment. For many risk managers, these models are considered difficult to use due to the difficulty of the prediction procedures included (Satchell and Knight, 2011).

Financial markets, are an event that will affect the market, attitude, new information entry, asymmetric information, legal regulations, macroeconomic effects etc. when faced with a situation, a change in price regimes may cause sudden leaps. In financial markets, increases and decreases in the index or securities price series above the averages can be defined as volatility. Since the existence of volatility is an important risk factor, it causes small investors to move away from the markets, it also causes decrease in transaction volume and speculators to make short term transactions. Determining the conditional volatility process has a key role in the risk management system (McNeil, Frey and Embrechts, 2015). In other words, it is very important for the market stakeholders to be able to predict volatility in advance, to maximize earnings or to keep losses to a minimum. For such reasons, the volatility forecast plays an important role in the financial markets and is of great importance to market stakeholders such as portfolio managers, market makers, investors and speculators. Estimation of volatility in financial markets will enable policy makers to make more effective decisions against potential breaks (Poon and Granger, 2003).

Political, economic, financial risks are seen to be high generally in the developing countries in which Turkey also takes part. These risks and reasons affecting the markets in many developing countries ensure that volatility in financial markets is at high levels. Effective estimation and modeling of these high volatility structures, especially for emerging markets, have been an important consideration. Many variants of these models have been developed since the research on the use of time series models for modeling volatility, the creation of the original ARCH model by Engle (1982) and generalization by Bollerslev (1986). In these developed models, the focus is on catching additional stylized phenomena observed in financial markets such as linear outsights and asymmetries. GARCH type models are among the tools required for risk managers today. 
An appropriate risk model should be able to adapt to the characteristics of financial returns. In recent academic studies, many financial assets have shown structural breaks in their volatility dynamics, and ignoring this feature may have a major impact on the precision of volatility estimates (Bauwens, Dufays and Rombouts, 2014; Lamoureux and Lastrapes, 1990).

One way of addressing regime change in the return process can be provided by the Markov Switching GARCH models (MS-GARCH), which allow parameters to change over time according to a variable that cannot be observed separately. These models can quickly adapt to structural changes in unconditional volatility, which leads to improved risk estimates. The parameters of GARCH models are generally assumed to be constant over time. However, the conditional distribution of financial returns differs between stagnation and expansion periods (Marcucci, 2005).

Lamoureux and Lastrapes (1990) stated that their high persistence in volatility may be due to structural changes in the variance process. In line with this view, Cai (1994) and Hamilton and Susmel (1994) independently combine the Markov switching model obtained in Hamilton $(1989,1990)$ with the ARCH specification and introduce the Markov Regime Switching ARCH model (MS-ARCH). The MS-ARCH model is designed to achieve regime changes in the volatility structure, using the unobservable state variable after the first order Markov Chain process. In other words, using this model, different parameter values will be obtained in different regime structures. Gray (1996), in his study, eliminated some of the problems that the MS-ARCH model contained and derived alternative MS-GARCH models. In the study by Klaassen (2002), Gray (1996) made changes in the model he obtained and stated that the model he obtained made predictions of better volatility.

In this study, it is aimed to evaluate the volatility of the BIST100 index representing Borsa Istanbul within the framework of the regime change approach. For this purpose, the logarithmic returns of the BIST100 index, which was created with the closing data of the period of 01.04.1993-20.04.2018, were analyzed with the MS-GARCH method, and volatility estimates and risk exposure values were obtained. In the second part of the study, there is a literature review, in the third part, data, methods and findings, and in the fourth part, the conclusion and discussion section can be seen.

This article aims to contribute to the literature by analyzing the return volatility of the BIST 100 Index with three-regime MS GARCH models. As a result of the literature research, it is seen that the volatility models for the BIST100 index applied with traditional single regime GARCH type models. However, it should not be ignored that it will exhibit different structures in its volatility in different market periods.

More accurate modeling of risk in financial markets is very important for both decision makers and investors. Unlike other studies in the literature that model BIST100 volatility using traditional GARCH structures, the determination of volatility dynamics for each regime by dividing the index into periods of low, standard and high volatility reveals the original value of this study.

Considering the log-likelihood and parameter significance, it was determined that the three regimes (low, standart and high volatility regimes) MS-GARCH model was suitable for the BIST100 index. Conditional average, ARCH, GARCH and asymmetry parameters were statistically significant. And volatility clusters has been identified for the BIST100 index. When 
the regime periods were examined, it was found that the BIST100 index was most likely to be in the standard regime. According to the weekly risk assessments, it was determined that the highest risk occurred on the 5th day during the low, standard and high regime periods.

The study consists of five parts: introduction, literature rewiew, data, method and findings and conclusion and discussion. In the following part of the study, a literature review on the subject is presented first, and then information about the data set and the method applied, and then empirical findings are examined. In the conclusion and discussion part of the study, a general evaluation was made.

\section{Literature Review}

Stock markets tend to fluctuate constantly, influenced by many positive and negative situations experienced by countries. When these positive or negative shocks experience a serious effect, risk-return performance will be significantly affected in parallel with this situation. Models that take into account regime change behavior are sensitive to repetitive market conditions such as stagnation and expansion, and financial crises or serious market crashes have increased the popularity of these models. Regime switching models are a suitable method for capturing these structural breaks in the financial market and fundamental changes in stock market dynamics.

Turner, Startz and Nelson (1989), Schaller and Norden (1997), Paye and Timmermann (2006), Henkel, Martin and Nardari (2011) found that stock market returns have changed over time and are subject to breaks and parameter instability. Maheu and McCurdy (2000) stated that stock markets display strong regime change behaviors using the Markov switching model, they separated market returns as bull and bear markets. Using the Markov model of change, Schwert (1989) stated that stock volatility was higher during the between the years 1929-1939 Great Depression and other periods of recession.

Stock market volatility is considered as an important indicator of business cycles. Tu (2017) emphasized that modeling taking different regime structures into account gives more realistic results for investors risk analysis. Cai (1994), Hamilton and Susmel (1994) were the first authors to use Markov switching models on financial time series. Excluding the lagged values of the conditional variance in the variance equation allows the probability function to be numerically computable. When using a GARCH type model, since it is a Markov chain with $\mathrm{K}$ regimes, the evaluation of probability requires the integration of all KT possible pathways, making the prediction impossible. The authors solved the problem of path dependence by eliminating the effects of regime-specific conditional variances. Gray (1996), Dueker (1997) and Klaassen (2002) focused on the solution of this road dependency problem. Gray (1996) suggested that the conditional distribution of returns is independent of the regime path and integrated of the regimes unobservable path in the GARCH equation with the conditional expectation of past variance. Other authors proposed alternative estimation methods to deal with the road dependency problem. While Francq and Zakoian (2008) use the generalized method of moments (GMM); Bauwens, Preminger and Rombouts (2010) used Bayesian MCMC techniques to predict MS. Augustyniak (2014) estimated the MS-GARCH model using Monte Carlo Expectation Maximization (MCEM) and Monte Carlo Maximum Likelihood (MCML) algorithms. 
In another recent study, Ardia, Bluteau, Boudt and Catania (2018) developed an estimation method that allows the GARCH process of each regime to develop independently from other regimes. It can be stated that this approach is advantageous in terms of both eliminating the road dependency problem and facilitating the interpretation of the variance dynamics of each regime. Ardia, Bluteau, Boudt, Catania and Trottier (2019) developed alternatives to this method using the MS-GARCH R Package. Due to this R program developed, possible to predict different types of GARCH type models (eg GARCH and Nelson (1991)). The authors used these models in different risk measures such as value at risk (VaR) and expected shortfall and found that MS-GARCH models gave better results compared to different single-regime GARCH-type models.

In the light of these developments, the applicability of MS-GARCH type models in financial markets have also increased. In parallel with these developments, the viability of MSGARCH type models in financial markets have increased. Moore and Wang (2007) discussed the stock market volatility of five new countries of the European Union (Czech Republic, Hungary, Poland, Slovenia and Slovakia) in the period 1994-2005. They determined that stock market indices showed high volatility before joining the European Union, and low volatility after joining the Union. Hu and Shin (2008) applied MS-GARCH modeling by using weekly stock market index data of developing countries in East Asia. Marcucci (2005), Wang and Theobald (2008), Visković, Arnerić and Rozga (2014), Abounoori, Elmi and Nademi (2016), Lolea and Vilcu (2018) and Korkpoe and Howard (2019) applied MS-GARCH models on various stock market indexes.

Ardia, Bluteau and Rüede (2019) found that the volatility structure of the bitcoin market shows regime changes. They stated that MS-GARCH models VaR) estimates give more accurate results compared to traditional single regime GARCH models.

In many empirical studies, the volatility structure of Borsa Istanbul (BIST) has been addressed using various GARCH type models, but the fact that the number of volatility estimates taking into account the regime change models has been encouraging for carrying out this study.

Kiliç (2007) analyzes long memory in ISE using the Fractional Integrated GARCH (FIGARCH) model and claims that ISE volatility is a long memory process. Mazibas (2005) compared the fifteen symmetrical and asymmetrical GARCH models in terms of estimation performance for daily, weekly and monthly volatility in ISE. Sevüktekin and Nargeleçekenler (2008) evaluated the performance of alternative models to estimate the volatility of the ISE 100 Index, using daily data in the 1987-2006 period. They stated that the most suitable conditional variance model among the alternative ARCH and GARCH models is GARCH $(1,1)$. Atakan (2009) the GARCH $(1,1)$ model was found to be the most suitable model in estimating the volatility related to the index mentioned. He determined that the volatility of the ISE-100 Index increased during the periods of crisis and uncertainty, and volatility clusters were experienced during these periods. Çağıl and Okur (2010) stated that there is a significant increase in volatility and the impact of the shock in the market will be felt for a longer time. Karabacak, Mecik and Genc (2014) investigated which GARCH type model is more suitable for modeling both the BIST100 index and the volatility of gold returns. They determined that shocks have asymmetrical effects and TGARCH $(1,1)$ model is suitable for BIST 100 index returns. Şahin (2016) used ARCH, GARCH, EGARCH and TGARCH models to compare the volatility of the 
BIST100 Index and the BIST Corporate Governance Index. According to the results obtained from the study, volatility clusters were observed in both return volatility, and the BIST100 Index had higher volatility than the BIST Corporate Governance Index. Kuzu (2018) discussed the return volatility of the BIST 100 Index with the ARCH, GARCH, EGARCH and TGARCH models, using the daily closing values for the 2011-2017 period. It has been determined that TGARCH model is the most suitable model for the estimation of BIST100 Index volatility.

Güriş and Saçıldı (2011) modeled the volatilities of the returns of the stocks traded on the ISE comparatively with the help of both classical and Bayesien GARCH models. They found that Bayesian models of GARCH type gave more significant results in modeling volatility structures of their returns compared to the traditional GARCH models. Gürsoy and Balaban (2014) used the GARCH $(1,1)$, EGARCH $(1,1)$ and GJR-GARCH $(1,1)$ models and solutions of the same models with the Support Vector Machines approach. GARCH models, which are solved with the Support Vector Machines approach, perform better than conventional GARCH models.

Çavdar and Aydın (2017) discussed the volatility of the BIST Corporate Governance Index with GARCH and SW-ARCH models. According the results the SW-ARCH model, which takes into account the regime change structure, is superior in measuring the volatility of the BIST Corporate Governance Index compared to the traditional GARCH models. Kula and Baykut (2017) aimed to determine the volatility structure of the index by using the daily closing values of the BIST Bank Index for the period of 02.01.1997-31.12.2016. It was determined that there is low risk regime persistence in BIST Bank Index and the index does not exhibit stability switching to low risk regime while in high risk regime. In BIST Bank Index, it was determined that volatility persistence was high in both regimes.

\section{Data, Method and Findings}

Borsa İstanbul, which has a developing financial market, is a high volatility stock market. Regimes considered to exist for volatility were handled in three categories: high regime, standard regime and low regime, and analyzes were carried out using three regime models. The standard regime period is considered as the period when the returns are stable, the high regime period is when the returns are above the standard regime, and the low regime is the period when the returns are below the standard period. In the analysis, the 01.04.1993-20.04.2018 period and BIST100 index closing data were used. The logarithms of the daily returns obtained from the index closing data were included in the analysis, and RStudio and Eviews package programs were used in the analysis.

In this study, which does not require ethics committee permission and legal permission, research and publication ethics have been followed.

The index and return charts of the BIST 100 index are presented in Figure 1. When Figure 1 is analyzed, it is possible to say that the BIST100 index series show an increasing trend and do not provide the stationary assumption sought in the series for time series analysis. Considering the BIST100 Yield graph, it is remarkable that the series are stationary and volatility clusters are experienced in some years. It is seen that these volatility clusters occurred in 1993, 1994, 1999, 2001, 2008 and 2013. It can be stated that this extreme volatility in the indices occurred during the periods of local and global financial crises and political crises. It can 
be observed that the index return series to be used for volatility prediction are distributed around zero mean and exhibit a stable structure. This observation was supported by using unit root tests. Results for unit root tests are shown in Table 1.
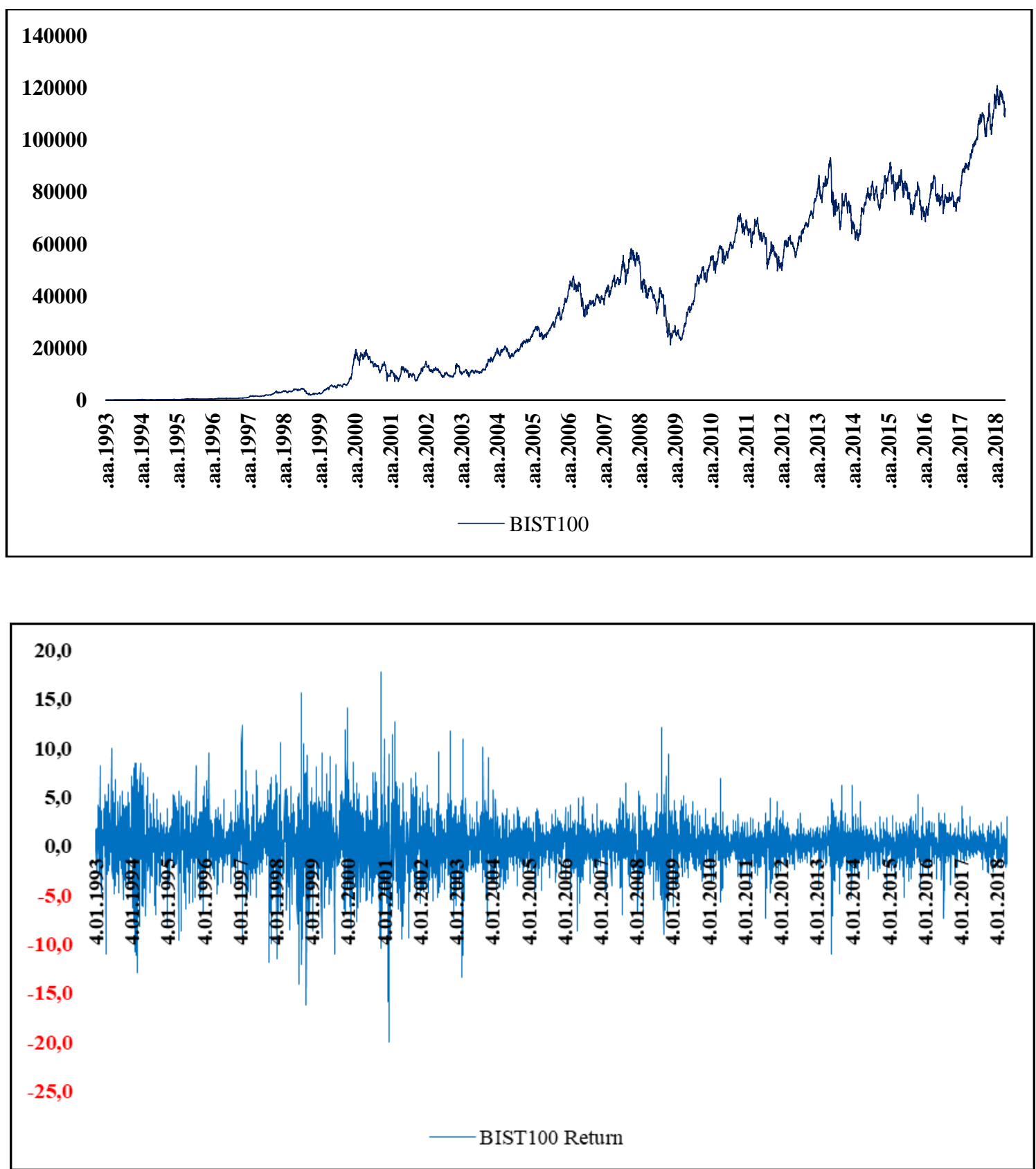

Figure 1. Index and Return Graphs Related to BIST100 Index

According to the descriptive statistics results, the average return on the BIST100 index was positive. While the maximum return calculated in the index is $17.73 \%$, the minimum return is $-19.97 \%$, the skewness coefficient is -0.0895 and the kurtosis coefficient is 8.4716 . It can be stated that the leptocurtic distribution feature, which is the negative skewness and the more flattened structure, which is frequently seen in the financial series, is seen in the BIST100 return series. The skewness and kurtosis coefficients also show that the BIST100 return series do not 
match the normal distribution as a result of Jarque-Bera test statistics. Financial data are generally stated in many studies where they do not provide the normal distribution assumption.

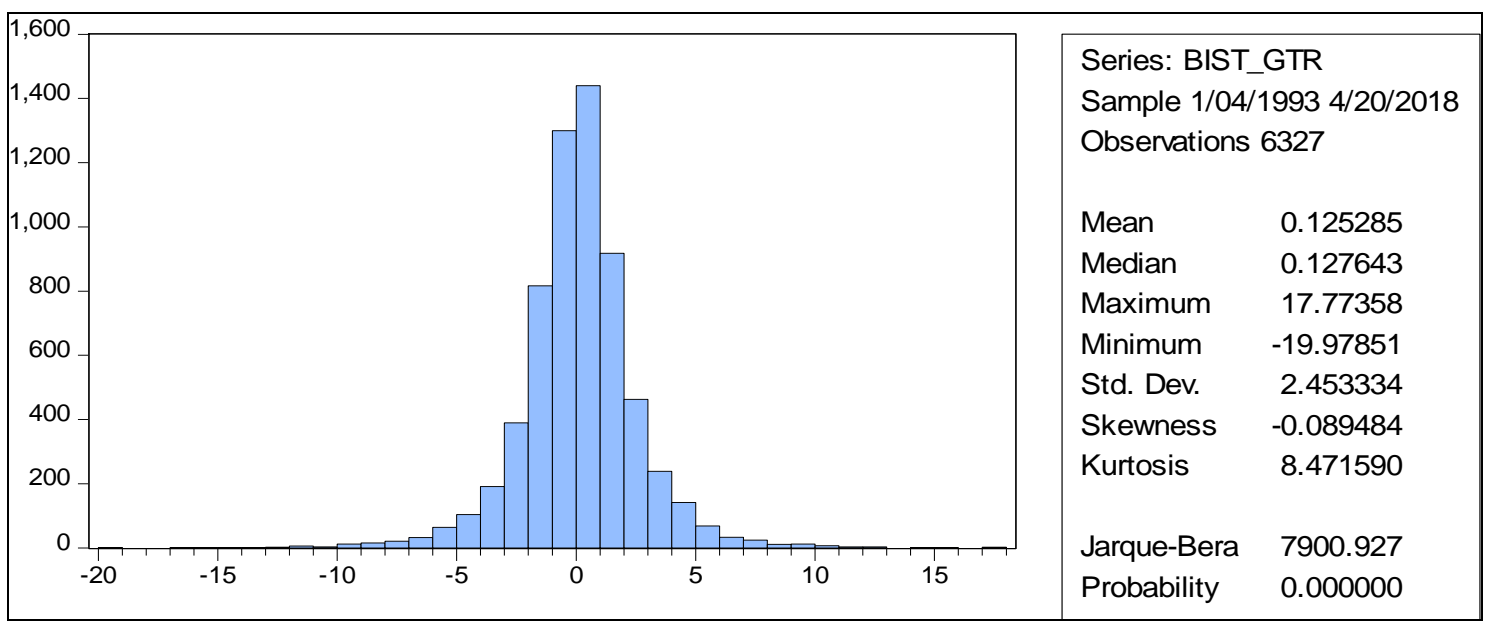

Figure 2. Descriptive Statistics

According to the ADF and PP unit root test results, it was determined that the probability value calculated for BIST100 index return values is less than 0.05 , which is considered as the critical value, and the null hypothesis that the series contain the unit root was rejected. The return series were found to be stationary, that is, I (0) according to both ADF and PP test results. It has been determined that the stability condition required for the time series analysis is met. Descriptive statistics for the return series are shown in Figure 2.

Table 1. Unit Root Test Results

\begin{tabular}{|c|c|c|c|c|c|c|}
\hline \multicolumn{7}{|c|}{ BIST 100 Return } \\
\hline & Test & Difference & Percent & $\begin{array}{c}\text { Critical } \\
\text { Value }\end{array}$ & t-Statistics & Probability \\
\hline \multirow{6}{*}{ 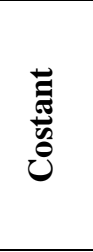 } & \multirow{3}{*}{ ADF } & \multirow{3}{*}{ Level } & $\% 1$ & -2.565 & \multirow{3}{*}{-75.540} & \multirow{3}{*}{0.000} \\
\hline & & & $\% 5$ & -1.941 & & \\
\hline & & & $\% 10$ & -1.617 & & \\
\hline & \multirow{3}{*}{$\mathbf{P P}$} & \multirow{3}{*}{ Level } & $\% 1$ & -2.565 & \multirow{3}{*}{-76.223} & \multirow{3}{*}{0.000} \\
\hline & & & $\% 5$ & -1.941 & & \\
\hline & & & $\% 10$ & -1.616 & & \\
\hline \multirow{6}{*}{ 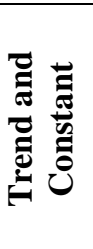 } & \multirow{3}{*}{ ADF } & \multirow{3}{*}{ Level } & $\% 1$ & -3.960 & \multirow{3}{*}{-75.835} & \multirow{3}{*}{0.000} \\
\hline & & & $\% 5$ & -3.411 & & \\
\hline & & & $\% 10$ & -3.127 & & \\
\hline & \multirow{3}{*}{$\mathbf{P P}$} & \multirow{3}{*}{ Level } & $\% 1$ & -3.959 & \multirow{3}{*}{-76.126} & \multirow{3}{*}{0.000} \\
\hline & & & $\% 5$ & -3.411 & & \\
\hline & & & $\% 10$ & -3.127 & & \\
\hline
\end{tabular}

$\mathrm{H}_{0}$ : BIST 100 Return has a unit root.

$\mathrm{H}_{1}$ : BIST 100 Return has not a unit root. (BIST 100 Return Stationary)

In order to perform volatility modeling, it is necessary to determine the presence of nonlinear states in the series along with variance and autocorrelation assumption tests. In case of variance, autocorrelation and linear exclusions in the series, ARCH / GARCH type models are needed to perform the volatility prediction. Accordingly, it was first investigated whether the 
variance of the error terms related to the BIST100 return series is fixed, i.e. whether it contains heteroscedasticity variance. ARCH-LM test was applied at alternative delays to detect the variance. The values related to the test results are given in Table 2.

When the ARCH-LM test results were examined, it was determined that the probability values calculated for all the delay values considered were below the critical value of 0.05 , and the null hypothesis, which stated that the variances of the error terms of the series were homoscedasticity, was rejected. Heteroscedasticity problem was determined in BIST100 return series. Another correlation for the volatility estimation, the autocorrelation assumption, was analyzed by examining the error terms correlograms. The results of the analysis are given in Table 3.

Table 2. ARCH-LM Heteroscedasticity Test Results

\begin{tabular}{lcccc}
\hline \multicolumn{3}{c}{ BIST100 Return } \\
\hline Lag & F Statistics & $\begin{array}{c}\text { F Statistics } \\
\text { Probability }\end{array}$ & Obs. $\mathbf{R}^{\mathbf{2}}$ & $\mathbf{R}^{\mathbf{2}}$ Probability \\
\hline Lag 1 & 582.829 & 0.000 & 533.732 & 0.000 \\
Lag 5 & 204.468 & 0.000 & 880.750 & 0.000 \\
Lag 21 & 55.6129 & 0.000 & 988.289 & 0.000 \\
Lag 63 & 22.0930 & 0.000 & 1148.415 & 0.000 \\
\hline $\mathrm{H}_{0}:$ Residuals are homoscedastic & & & \\
$\mathrm{H}_{1}:$ Residuals are heteroscedastic & & & \\
\hline
\end{tabular}

It is determined that the probability values of the $\mathrm{Q}$ statistic expressed in Table 3 are smaller than the critical value of 0.05 , considering all lagged values. Accordingly, it can be said that the series contain autocorrelation problem. After determining autocorrelation and changing variance presence in BIST100 index return series, it is necessary to determine the presence of nonlinear elements in the series. The presence of nonlinear elements requires the use of GARCH-type models in volatility modeling. The BDS Linearity test proposed by Broock, Scheinkman, Dechert and Le Baron (1996) was used to determine the linearity. Results for the BDS test are shown in Table 4.

Table 3. Correlogram of Error Terms

\begin{tabular}{lcccc}
\hline \multicolumn{5}{c}{ BIST100 Returns } \\
\hline AC & Lag 1 & Lag 5 & Lag 21 & Lag 63 \\
PAC & 0.049 & -0.025 & -0.002 & 0.012 \\
Q-Statstics & 0.049 & -0.027 & 0.002 & 0.007 \\
Probability & 15.179 & 29.068 & 73.512 & 154.370 \\
\hline
\end{tabular}

When the BDS test results were examined, it was seen that the probability value of the BDS test for the return series was below the critical level of 0.05 , and the null hypothesis that the series did not contain non-linear elements was rejected. The necessity of GARCH type models in volatility modeling was revealed with the series containing non-linear elements. In the study, it was analyzed with MS-GARCH models, 
which make more effective volatility predictions than volatility models containing nonlinear elements.

Table 4. BDS Linearity Test Results

\begin{tabular}{cccccc}
\hline & Dimension & BDS Statistics & Standart & Z-Statistics & Probability \\
\hline \multirow{8}{*}{} & 2 & 0.026 & 0.001 & 22.019 & 0.000 \\
& 3 & 0.056 & 0.001 & 29.361 & 0.000 \\
$\mathbf{6}$ & 4 & 0.077 & 0.002 & 34.254 & 0.000 \\
& 5 & 0.091 & 0.002 & 38.791 & 0.000 \\
& 6 & 0.099 & 0.002 & 43.484 & 0.000 \\
\hline
\end{tabular}

Classical ARCH-GARCH models are based on the assumption that the data set being linear is linear, but observing nonlinear structures especially in long-term data sets causes misleading results with classical models. At this point, the Markov change approach has been proposed as an alternative by Hamilton (1990) in order to determine the statistical definition of the "milestones" of a time series. These models allow a time series that exhibit various volatility structures to frequently switch between regimes through an unobservable regime variable. Changes in regimes can also be estimated by multiple regimes in $s_{k}$ format. The transition probability matrix of the three-regime and first-order Markov process is equal to the $\mathrm{P}$ matrix, which is expressed below:

$$
P=\left(\begin{array}{lll}
p_{11} & p_{12} & p_{13} \\
p_{21} & p_{22} & p_{23} \\
p_{31} & p_{32} & p_{33}
\end{array}\right)
$$

Here $p_{i j}$ denotes the probability of a change from the $\mathrm{i}$ regime to the $\mathrm{j}$ regime. The sum of the possibilities in the whole regime period is equal to $1\left(\sum_{j=1}^{3} p_{i j}=1\right)$. The mean and variance of the $s_{t}$ regime are expressed as a linear function of $s_{t}$ as follows.

$$
\begin{gathered}
\mu_{s_{t}=} \mu_{1} s_{1 t}+\mu_{2} s_{2 t}+\mu_{3} s_{3 t} \\
\sigma_{s_{t}}^{2}=\sigma_{1}^{2} s_{1 t}+\sigma_{2}^{2} s_{2 t}+\sigma_{3}^{2} s_{3 t}
\end{gathered}
$$

Using the equations, the model can be written as follows.

$$
\begin{gathered}
y_{t}=\mu_{1} s_{1 t}+\mu_{2} s_{2 t}+\mu_{3} s_{3 t}+z_{t} \\
z_{t}=\sum_{k=1}^{2} \varphi_{k, s_{t}} z_{t-k}+\left(\sigma_{1}^{2} s_{1 t}+\sigma_{2}^{2} s_{2 t}+\sigma_{3}^{2} s_{3 t}\right)^{1 / 2} \varepsilon_{t}
\end{gathered}
$$

If $t=1, \ldots, T$ and $s_{t}$ depending on the condition, the combined conditional log-likelihood function of $y_{t}$ can be shown as follows.

$$
\log f\left(y_{T}, \ldots, y_{N} \mid s_{T}, s_{T-1}, \ldots\right)=-\left(\frac{T}{2}\right) \ln 2 \pi-\sum_{t=n}^{T}\left[\ln \sigma_{s_{t}}+\frac{v_{t}^{2}}{2 \sigma_{s_{t}}^{2}}\right]
$$


Where $v_{t}=z_{t}-\varphi_{1, s_{t}} z_{t-1}+\varphi_{2, s_{t}} z_{t-2}=\sigma_{s_{t}} \varepsilon_{t}$. Since the $\sigma_{s_{t}}$ variable cannot be observed and the $y_{t}$ series are known, the current situation can be obtained by making use of the historical data. Model parameters indicated that the log-likelihood equation proposed by Hamilton (1989) can be estimated using the nonlinear approach as shown below.

$$
f\left(y_{T}, \ldots, y_{n}\right)=\prod_{t=n}^{T} f\left(y_{t} \mid y_{t-1}, y_{t-2}, \ldots, y_{1}\right)
$$

In the study, modeling of the BIST100 return series was carried out by using GARCH type models for each regime period within the framework of the Markov switching structure. Estimation was made by using Markov change EGARCH-SGARCH-EGARCH models, which are tested for each regime. As a result of the model comparisons, the skewed generalized error distribution (sged) was used for the 1st and 2nd regimes, while the skewed student (sstd) distribution was chosen for the 3rd regime. Bollerslev (1987) stated that, since the general feature of time serial data is fat tail, it would be appropriate to prefer Student-t distribution in GARCH models. Ural and Adakale (2009) stated that Student-t distribution shows a symmetrical distribution similar to the normal distribution. The results for the estimated volatility model are presented in Table 5.

Conditional mean parameters $(\alpha 01, \alpha 02, \alpha 03)$ were found statistically significant. The $\operatorname{ARCH}(\alpha 11, \alpha 12, \alpha 13)$ and GARCH $(b 1, b 2, b 3)$ parameters of the MS-GARCH model are statistically significant, which means that there are conditional variance effects. When we look at parameters $\alpha 21, \alpha 23$ it is seen that the parameters are significant, the effects on volatility are asymmetric. It is possible to say that the negative coefficients have a leverage effect in the stock market, that is, negative shocks that may occur cause more volatility than positive shocks. Mazibas (2005), Kuzu (2018) Karabacak et al. (2014) determined the precence of asymmetric effects for the BIST100 index with single regime models. According to our findings, the presence of an asymmetrical effect was detected in low and high regimes. Student-t and Skewed Student-t distribution parameters were found statistically positive and significant, indicating that the distribution of returns is not normal and skewed to the right. ARCH effect parameters appear to be quite low compared to the GARCH effect parameters. This shows that when the regime changes from a low volatility to a high volatility period, the $\mathrm{ARCH}$ parameter decreases and the GARCH parameter increases. It can be stated that the previous volatility values were a more important factor for BIST100 returns during thehigh volatility periods. In the three main regimes in which the BIST 100 yields are separated, the probability of acting under the standard regime is $79.69 \%$, the probability of continuing under the low regime is $17.43 \%$, and the probability of acting under the high regime is $2.87 \%$. According to this result, volatility analysis with the MS-GARCH method in order to make accurate and reliable decisions will guide the individual or institutional investors in determining what they have to do correctly in their evaluations on the BIST100 index. Similarly, Satoyoshi (2012) and Škrinjarić and Šego (2016) stated that the in-sample and non-sample period volatility estimates of MS-GARCH models in Japan and Croatia stock markets are a good guide for investors. 
Table 5. Model Estimation Results

\begin{tabular}{|c|c|c|c|c|}
\hline & Parameter & Std. Error & t-Statistics & Probability \\
\hline \multicolumn{5}{|l|}{ Regime 1} \\
\hline$\alpha_{01}$ & 0.004 & 0.003 & 1.323 & 0.092 \\
\hline$\alpha_{11}$ & 0.090 & 0.017 & 5.239 & 0.000 \\
\hline$\alpha_{21}$ & -0.034 & 0.010 & -3.383 & 0.000 \\
\hline$b_{1}$ & 0.991 & 0.002 & 4.050 & 0.000 \\
\hline$q_{1}$ & 1.747 & 0.088 & 1.985 & 0.000 \\
\hline$\varphi_{1}$ & 0.983 & 0.026 & 3.836 & 0.000 \\
\hline \multicolumn{5}{|l|}{ Regime 2} \\
\hline$\alpha_{02}$ & 0.135 & 0.082 & 1.628 & 0.051 \\
\hline$\alpha_{12}$ & 0.024 & 0.027 & 9.847 & 0.162 \\
\hline$b_{2}$ & 0.970 & 0.003 & 3.925 & 0.000 \\
\hline$q_{2}$ & 1.401 & 0.122 & 1.150 & 0.000 \\
\hline$\varphi_{2}$ & 0.780 & 0.043 & 1.800 & 0.000 \\
\hline \multicolumn{5}{|l|}{ Regime 3} \\
\hline$\alpha_{03}$ & 1.227 & 0.639 & 1.919 & 0.027 \\
\hline$\alpha_{13}$ & 0.707 & 0.189 & 3.743 & 0.000 \\
\hline$\alpha_{23}$ & -0.272 & 0.108 & -2.519 & 0.000 \\
\hline$b_{3}$ & 0.648 & 0.180 & 3.602 & 0.000 \\
\hline$q_{3}$ & 96.534 & 0.004 & 2.778 & 0.000 \\
\hline$\varphi_{3}$ & 1.897 & 0.523 & 3.627 & 0.000 \\
\hline \multicolumn{5}{|c|}{ Transition Probabilities } \\
\hline$p_{11}$ & 0.971 & 0.083 & 1.166 & 0.000 \\
\hline$p_{12}$ & 0.029 & 0.000 & 1.116 & 0.000 \\
\hline$p_{21}$ & 0.131 & 0.010 & 1.310 & 0.000 \\
\hline$p_{22}$ & 0.854 & 0.051 & 1.660 & 0.000 \\
\hline$p_{31}$ & 0.000 & 0.000 & 6.000 & 0.499 \\
\hline$p_{32}$ & 0.094 & 0.007 & 1.329 & 0.000 \\
\hline \multicolumn{5}{|c|}{ Possibility to Stay in the Same Regime } \\
\hline & $\begin{array}{c}\text { Low } \\
(0.174)\end{array}$ & $\begin{array}{l}\text { Standart } \\
(0.797)\end{array}$ & $\begin{array}{l}\text { High } \\
(0.029)\end{array}$ & \\
\hline \multicolumn{5}{|c|}{ Model Criteria } \\
\hline Log-Lik. & -13328.950 & & & \\
\hline AIC & 26703.910 & & & \\
\hline BIC & 26859.220 & & & \\
\hline
\end{tabular}

Conditional variances in volatility models are estimated by maximizing the likelihood function calculated as logarithmic components of their estimated errors. Conditional volatilities obtained as a result of model prediction are shown in Figure 3.

Figure 3 shows the dates with the highest changes in BIST100 returns for the working period of 4.1.1993-20.04.2018. According to the figure conditional variance, the April 5, 1994 extraordinary stabilization program, the political instability in 1995 and the early December 24 elections, the 1998 elections, the government's confidence on January 16, 1999, the crises of November 2000 and February 2001, the financial global crisis that emerged at the end of 2008 and June 12 has the highest values. It is seen that the periods corresponding to the realization of the 2011 elections are reflected on the chart. 


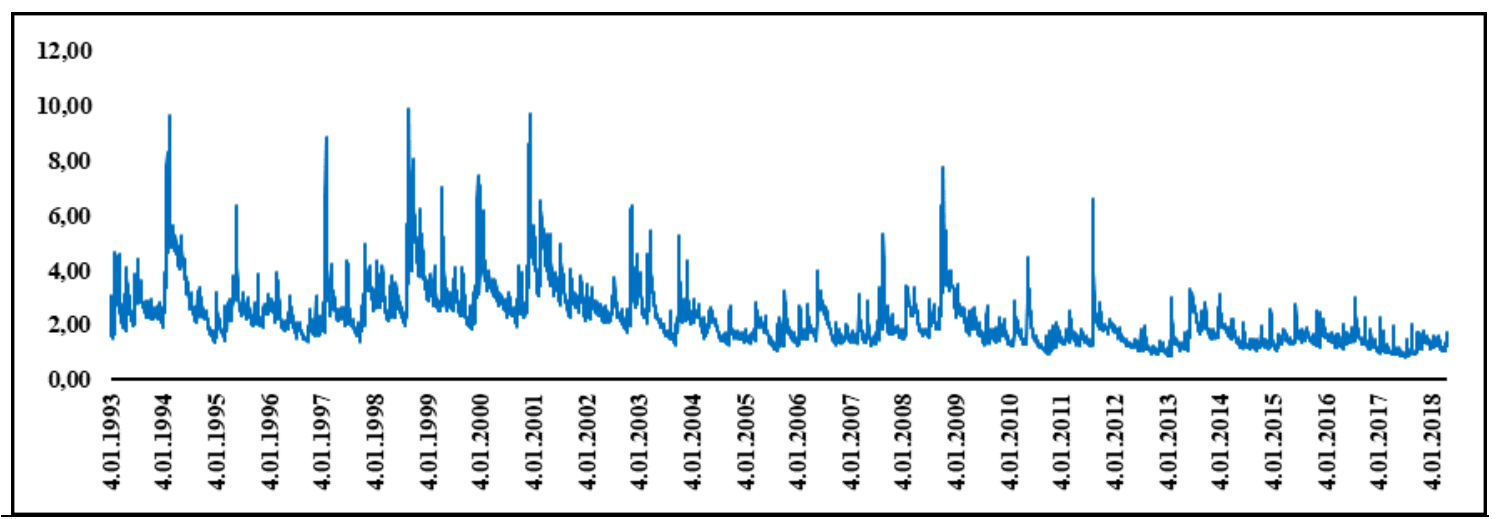

Figure 3. Conditional Volatilities

Transition possibilities between volatility regimes in Table 6, Table 7 and Table 8 are presented for periods of 1,5 and 20 days, respectively. When Table 6 is examined, it is determined that the regression 1 , which represents the standard volatility regime in one day, has a probability of driving 0.997 , the probability of transition from regime 1 to a low volatility regime is 0.029 and the probability of transition from regime 1 to a high volatility regime is 0.000 . The probability of staying in regime 2 representing the low regime was 0.854 , the probability of transition from regime 2 to regime 1 was 0.131 , and the probability of transition from regime 2 to regime 3 was 0.015 . It is determined that the probability of staying in regime 3 , which represents a high volatility regime, is 0.906 , the probability of transition from regime 3 to regime 1 is 0.000 , and the probability of transition from regime 3 to regime 2 is 0.094 .

Table 6. One-Day Regime Transition Probability Estimates

\begin{tabular}{lccc}
\hline & Regime 1 & Regime 2 & Regime 3 \\
\hline Regime 1 & 0.971 & 0.029 & 0.000 \\
Regime 2 & 0.131 & 0.854 & 0.015 \\
Regime 3 & 0.000 & 0.094 & 0.906 \\
\hline
\end{tabular}

Table 7. Five-Day Regime Transition Probability Forecasts

\begin{tabular}{lccc}
\hline & Regime 1 & Regime 2 & Regime 3 \\
\hline Regime 1 & 0.895 & 0.101 & 0.003 \\
Regime 2 & 0.463 & 0.490 & 0.047 \\
Regime 3 & 0.093 & 0.285 & 0.622 \\
\hline
\end{tabular}

Table 8. Twenty-Day Regime Transition Probability Estimates

\begin{tabular}{lccc} 
& Regime 1 & Regime 2 & Regime 3 \\
\hline Regime 1 & 0.813 & 0.167 & 0.021 \\
Regime 2 & 0.761 & 0.196 & 0.043 \\
Regime 3 & 0.571 & 0.261 & 0.168 \\
\hline
\end{tabular}

According to Table 7, considering the five-day regime change possibilities, the probability of staying in Regime 1, which represents the standard volatility regime, was 0.895 . The probability of transition to Regime 2, which represents a period of less than Regime 1, is 0.101 , and the probability of transition to Regime 3 , which represents a period of high volatility 
from Regime1, is determined as 0.003 . The probability of staying in regime 2 representing the low regime was 0.490 , the probability of transition from regime 2 to regime 1 was 0.446 , and the probability of transition from regime 2 to regime 3 was 0.622 . It is determined that the probability of staying in regime 3 , which is a high regime, is 0.622 , the probability of transition from regime 3 to regime 1 is 0.093 , and the probability of transition to regime 2 is 0.285 .

When Table 8 is analyzed, it is determined that the regression 1, which represents the standard volatility regime in the twenty-day period, is 0.813 , the probability of transition from regime 1 to the low regime is 0.167 and the probability of transition from regime 1 to the high regime is 0.021 . The probability of staying in regime 2 , which represents the low regime, was determined as 0.195 , the probability of transition from regime 2 to regime 1 was 0.761 , and the probability of transition from regime 2 to regime 3 was 0.0423 . The probability of staying in regime 3 , which is a high regime, is 0.168 , the probability of transition from regime 3 to regime 1 is 0.571 , and the probability of transition from regime 3 to regime 2 is 0.261 .

Table 9. VaR Values Based on Regimes

\begin{tabular}{cccc}
\hline Days & Low Regime & Standart Regime & High Regime \\
\hline 1 & -2.021 & -4.326 & -4.796 \\
2 & -1.988 & -4.302 & -5.804 \\
3 & -1.976 & -4.485 & -6.660 \\
4 & -2.007 & -4.384 & -7.233 \\
5 & -2.035 & -4.486 & -7.640 \\
\hline
\end{tabular}

Considering the probability of acting in regimes, it can be stated that the continuity of the regime is the most probable period in a one-day period, in the twenty-day period. It can be stated that the volatility has decreased partially and the possibility of transition from regime 2 and regime 3 to the standard regime 1 is high.

The five-day VaR results of the regimes for the BIST 100 returns are presented in Table 9. When Table 8, which shows VaR values based on regimes, is analyzed, it is determined that the highest risk of harm in the low, standard and high regime will be at the 5th day and $2.035 \%$, $4.486 \%$ and $7.640 \%$ respectively.

VaR values of our three regime MS-GARCH model that we prepared in accordance with the purpose of the study are given in Table 10. When Table 10 is examined, if the model is evaluated as a whole, the probability of damaging statistically at the level of $1 \%$ and 5\% increases to the highest level on the 5th day as in regimes. On the 5th day, the probability of loss at $1 \%$ significance level was $4.408 \%$ and at $5 \%$ significance level it was $2.408 \%$.

Table 10. VaR Values of the Model

\begin{tabular}{ccc}
\hline Days & $\mathbf{\%} \mathbf{1}$ & $\mathbf{\%} \mathbf{5}$ \\
\hline 1 & -3.984 & -2.319 \\
2 & -4.094 & -2.269 \\
3 & -4.396 & -2.398 \\
4 & -4.363 & -2.328 \\
5 & -4.408 & -2.408 \\
\hline
\end{tabular}




\section{Conclusion and Discussion}

In the study aiming to determine the volatility structure of the BIST100 Index with the MS-GARCH model, BIST100 index closing data for the period of 01.04.1993-20.04.2018 was used. Detection of regimes presence was analyzed by three regime MS-GARCH model. The basic assumption of analyzing with time series is that the series are stationary. For this reason, BIST100 index logarithmic returns were primarily tested with Augmented Dickey-Fuller (ADF) and Philips-Perron (PP) unit root tests and the series were found to be stationary at the level. In addition, the Student-t and Skewed Student-t distribution parameters were found statistically positive and significant, indicating that the distribution of returns is not normal and skewed to the right. The yield $(\mathrm{Q})$ and checkered returns $(\mathrm{Q} 2)$ of the Ljung-Box statistics were found to be significant, indicating that the BIST 100 index returns show a high degree of volatility clustering behavior.

The three-regime MS-GARCH model created was estimated by four different models. In the model estimations, it is determined that MS-EGARCH-SGARCH-EGARCH (S-Student) model gives the best results. As a result of the analysis, conditional average parameters $\left(\alpha_{01}, \alpha_{02}, \alpha_{03}\right)$ were found statistically significant. ARCH $\left(\alpha_{11}, \alpha_{12}, \alpha_{13}\right)$, GARCH $\left(b_{1}, b_{2}, b_{3}\right)$ and asymmetry $\left(\alpha_{21}, \alpha_{23}\right)$ parameters in the MS-GARCH model were found to be statistically significant, indicating that they had conditional variance effects. It is seen that ARCH effect parameters are quite low compared to GARCH effect parameters. This shows that when the regime passes from a low volatility to a high volatility period, the $\mathrm{ARCH}$ parameter decreases and the GARCH parameter increases. This shows that the previous volatility values are a more important factor for BIST100 returns during high volatility periods.

In addition, when the probability of the transitions between the regimes is analyzed, it is determined that the probability of the standard regime period to be realized within one day period is 0.970 , the probability of transition from the standard regime to the low volatility regime is 0.029 and the probability of transition from the regime to the high volatility regime is 0.000. When looked at the five-day regime change possibilities it can be seen that the probability of staying in the standard volatility regime is 0.895 , the probability of transition from the standard regime to the low period is 0.101 , and the probability of transition from the standard regime to the high volatility period is 0.003 . When the series are examined in 20-day periods, it is determined that the probability of staying in the standard regime is 0.812 , the probability of transition from the standard regime to the low regime is 0.160 and the probability of transition from the standard regime to the high regime is 0.020 .

As a result, it was determined that the BIST 100 index representing Borsa Istanbul has standard, high and low volatility regimes. In the securities markets, it is an important factor that speculators, who are an important actor besides investors, can accurately predict the volatility that may occur in order to reveal their future expectations. It is important to be able to estimate the volatility accurately and to estimate the transition possibilities between regimes, to keep the gains maximized and losses to a minimum. For this reason, it will be appropriate for Borsa İstanbul stakeholders and especially institutional and individual investors to make volatility analysis considering the three-regime MS-GARCH model to make the right investment decisions. MS-GARCH model takes the regime transition possibilities determined in the study into account and making investment decisions according to the expectations that are appropriate for the risk levels of the investors. Attracting small investors to the markets, increasing the 
A. Kaya \& İ. Y.Yarbaş1, "Forecasting of Volatility in Stock Exchange Markets By MS-GARCH Approach: An Application of Borsa Istanbul"

transaction volume, attracting long-term investments, increasing the market depth and creating a reliable and low-risk investment environment can be achieved by reducing volatility. In order to achieve this situation, it will be effective to expand the environment of trust and transparency to the market. It will also be effective to raise awareness of social savings, and to carry out studies to ensure that funds are transferred to capital markets.

\section{Researchers Contribution Rate Statement}

The authors declare that they have contributed equally to the article.

\section{Conflict of Interest Statement}

There is no potential conflict of interest in this study. 


\section{References}

Abounoori, E., Elmi, Z. M. and Nademi, Y. (2016). Forecasting Tehran stock exchange volatility; Markov switching GARCH approach. Physica A: Statistical Mechanics and its Applications, 445, 264-282. https://doi.org/10.1016/j.physa.2015.10.024

Ardia, D. (2008). Financial risk management with Bayesian estimation of GARCH models. Heidelberg: Springer. doi:10.1007/978-3-540-78657-3

Ardia, D., Bluteau, K. and Rüede, M. (2019). Regime changes in Bitcoin GARCH volatility dynamics. Finance Research Letters, 29, 266-271. https://doi.org/10.1016/j.frl.2018.08.009

Ardia, D., Bluteau, K., Boudt, K. and Catania, L. (2018). Forecasting risk with Markov-switching GARCH models: A large-scale performance study. International Journal of Forecasting, 34(4), 733-747. https://doi.org/10.1016/j.ijforecast.2018.05.004

Ardia, D., Bluteau, K., Boudt, K., Catania, L. and Trottier, D. A. (2019). Markov-switching GARCH models in R: The MSGARCH package. Journal of Statistical Software, 91(4). doi:10.18637/jss.v091.i04

Atakan, T. (2009). İstanbul Menkul Kiymetler Borsasında değişkenliğin (volatilitenin) ARCH-GARCH yöntemleri ile modellenmesi. Yönetim Dergisi, 62, 48-61. Retrieved from https://app.trdizin.gov.tr/

Augustyniak, M. (2014). Maximum likelihood estimation of the Markov-switching GARCH model. Computational Statistics \& Data Analysis, 76, 61-75. https://doi.org/10.1016/j.csda.2013.01.026

Bauwens, L., Dufays, A. and Rombouts, J. V. (2014). Marginal likelihood for Markov-switching and change-point GARCH models. Journal of Econometrics, 178, 508-522. https://doi.org/10.1016/j.jeconom.2013.08.017

Bauwens, L., Preminger, A. and Rombouts, J. V. (2010). Theory and inference for a Markov switching GARCH model. The Econometrics Journal, 13(2), 218-244. doi:10.1111/j.1368423X.2009.00307.x

Bollerslev, T. (1986). Generalized autoregressive conditional heteroskedasticity. Journal of Econometrics, 31(3), 307-327. https://doi.org/10.1016/0304-4076(86)90063-1

Bollerslev, T. (1987) A conditionally heteroskedastic time series model for speculative prices and rates of return. The Review of Economics and Statistics, 69(3), 542-547. https://doi.org/10.2307/1925546

Broock, W. A., Scheinkman, J. A., Dechert, W. D. and LeBaron, B. (1996). A test for independence based on the correlation dimension. Econometric Reviews, 15(3), 197-235. https://doi.org/10.1080/07474939608800353

Cai, J. (1994). A Markov model of switching-regime ARCH. Journal of Business \& Economic Statistics, 12(3), 309-316. Retrieved from https://www.tandfonline.com/

Çağıl, G. ve Okur, M. (2010). 2008 küresel krizinin İMKB hisse senedi piyasası üzerindeki etkilerinin GARCH modelleri ile analizi [The analysis of the impact of 2009 global crisis on the ISE stock market using GARCH models]. Marmara Üniversitesi İktisadi ve İdari Bilimler Dergisi, 28(1), 573-585. Retrieved from https://dergipark.org.tr/en/pub/muiibd

Çavdar, Ş. Ç. ve Aydın, A. D. (2017). Borsa İstanbul Kurumsal Yönetim Endeksi’nde (XKURY) volatilitenin etkisi: ARCH, GARCH ve SWARCH modelleri ile bir inceleme [The effect of volatility in the Borsa Istanbul Corporate Governance Index (XKURY): An examination with the ARCH, GARCH AND SWARCH models]. Süleyman Demirel Üniversitesi İktisadi ve İdari Bilimler Fakültesi Dergisi, 22(3), 697-711. Retrieved from https://dergipark.org.tr/en/pub/sduiibfd/

Dueker, M. J. (1997). Markov switching in GARCH processes and mean-reverting stock-market volatility. Journal of Business \& Economic Statistics, 15(1), 26-34. https://doi.org/10.1080/07350015.1997.10524683 
Engle, R. F. (1982). Autoregressive conditional heteroscedasticity with estimates of the variance of United Kingdom inflation. Econometrica: Journal of the Econometric Society, 987-1007. https://doi.org/10.2307/1912773

Francq, C. and Zakoian, J. M. (2008). Deriving the autocovariances of powers of Markov-switching GARCH models, with applications to statistical inference. Computational Statistics \& Data Analysis, 52(6), 3027-3046. https://doi.org/10.1016/j.csda.2007.08.003

Gray, S. F. (1996). Modeling the conditional distribution of interest rates as a regime-switching process. Journal of Financial Economics, 42(1), 27-62. https://doi.org/10.1016/0304-405X(96)00875-6

Güriş, S. ve Saçıldı, İ. S. (2011). İstanbul Menkul Kıymetler Borsası'nda hisse senedi getiri volatilitesinin klasik ve Bayesyen GARCH modelleri ile analizi [Analysis of stock return volatility using classical and Bayesian GARCH models in Istanbul Stock Exchange]. Trakya Üniversitesi Sosyal Bilimler Dergisi, 13(2), 153-171. Retrieved from https://dergipark.org.tr/en/pub/trakyasobed/

Gürsoy, M. ve Balaban, M. (2014). Hisse senedi getirilerindeki volatilitenin tahminlenmesinde destek vektör makinelerine dayalı GARCH modellerinin kullanımı [Volatility forecasting in stock returns using support vector machines based GARCH models]. Kafkas Üniversitesi Iktisadi ve Idari Bilimler Fakültesi Dergisi, 5(8), 167-186. Retrieved from https://dergipark.org.tr/tr/pub/kauiibf

Hamilton, J. D. (1989). A new approach to the economic analysis of nonstationary time series and the business cycle. Econometrica: Journal of the Econometric Society, 357384. https://doi.org/10.2307/1912559

Hamilton, J. D. (1990). Analysis of time series subject to changes in regime. Journal of Econometrics, 45(1-2), 39-70. https://doi.org/10.1016/0304-4076(90)90093-9

Hamilton, J. D. and Susmel, R. (1994). Autoregressive conditional heteroskedasticity and changes in regime. Journal of Econometrics, 64(1-2), 307-333. https://doi.org/10.1016/0304-4076(94)900671

Henkel, S. J., Martin, J. S. and Nardari, F. (2011). Time-varying short-horizon predictability. Journal of Financial Economics, 99(3), 560-580. https://doi.org/10.1016/j.jfineco.2010.09.008

Hu, L. and Shin, Y. (2008). Optimal test for Markov switching GARCH models. Studies in Nonlinear Dynamics \& Econometrics, 12(3). Retrieved from http://citeseerx.ist.psu.edu/

Karabacak, M., Meçik, O. ve Genç, E. (2014). Koşullu değişen varyans modelleri ile BİST 100 endeks getirisi ve altın getiri serisi volatilitesinin tahmini. Alanya Isletme Fakültesi Dergisi, 6(1). Retrieved from https://web.a.ebscohost.com/

Kiliç, R. (2007). Conditional volatility and distribution of exchange rates: GARCH and FIGARCH models with NIG distribution. Studies in Nonlinear Dynamics \& Econometrics, 11(3). https://doi.org/10.2202/1558-3708.1430

Klaassen, F. (2002). Improving GARCH volatility forecasts with regime-switching GARCH. In J. D. Hamilton and B. Raj (Eds.), Advances in Markov-switching models (pp. 223-254). https://doi.org/10.1007/978-3-642-51182-0

Korkpoe, C. H. and Howard, N. (2019). Volatility model choice for Sub-Saharan frontier equity marketsa Markov Regime Switching Bayesian approach. EMAJ: Emerging Markets Journal, 9(1), 69-79. doi:10.5195/emaj.2019.172

Kula, V. ve Baykut, E. (2017). BIST Banka Endeksi'nin (XBANK) volatilite yapısının Markov rejim değişimi GARCH modeli (MSGARCH) ile analizi [An analysis of the volatility structure of BIST Bank (XBANK) index by a Markov regime switching GARCH (MSGARCH) model]. Bankacllar Dergisi, 28(2), 89-110. Retrieved from https://www.tbb.org.tr/

Kuzu, S. (2018). Borsa İstanbul Endeksi (BİST 100) getiri volatiletesinin ARCH ve GARCH modeli ile tahmin edilmesi [Prediction of stock exchange Istanbul Index (BIST 100) return volatility with ARCH and GARCH models]. Muhasebe ve Vergi Uygulamalarl Dergisi, 608-624. Retrieved from https://dergipark.org.tr/en/pub/muvu/ 
Lamoureux, C. G. and Lastrapes, W. D. (1990). Heteroskedasticity in stock return data: Volume versus GARCH effects. The Journal of Finance, 45(1), 221-229. https://doi.org/10.1111/j.15406261.1990.tb05088.x

Lolea, I. C. and Vilcu, L. C. (2018). Measures of volatility for the Romanian Stock Exchange: A regime switching approach. Paper presented at the Proceedings of the International Conference on Business Excellence (pp. 544-556). Sciendo. https://doi.org/10.2478/picbe-2018-0049

Maheu, J. M. and McCurdy, T. H. (2000). Identifying bull and bear markets in stock returns. Journal of Business \& Economic Statistics, 18(1), 100-112. Retrieved from https://www.tandfonline.com/

Marcucci, J. (2005). Forecasting stock market volatility with regime-switching GARC models. Studies in Nonlinear Dynamics \& Econometrics, 9(4), s. 1-53. https://doi.org/10.2202/1558-3708.1145

Mazibas, M. (2005). IMKB piyasalarındaki volatilitenin modellenmesi ve öngörülmesi: Asimetrik GARCH modelleri ile bir uygulama. Retrieved from https://papers.ssrn.com/

McNeil, A. J., Frey, R. and Embrechts, P. (2015). Quantitative risk management: Concepts, techniques and tools-revised edition. New Jersey: Princeton university press.

Moore, T. and Wang, P. (2007). Volatility in stock returns for new EU member states: Markov regime switching model. International Review of Financial Analysis, 16(3), 282-292. https://doi.org/10.1016/j.irfa.2007.03.006

Nelson, D. B. (1991). Conditional heteroskedasticity in asset returns: A new approach. Econometrica: Journal of the Econometric Society, 59(2), 347-370. https://doi.org/10.2307/2938260

Paye, B. S. and Timmermann, A. (2006). Instability of return prediction models. Journal of Empirical Finance, 13(3), 274-315. https://doi.org/10.1016/j.jempfin.2005.11.001

Poon, S. H. and Granger, C. W. (2003). Forecasting volatility in financial markets: A review. Journal of Economic Literature, 41(2), 478-539. doi:10.1257/002205103765762743

Satchell, S. and Knight, J. (2011). Forecasting volatility in the financial markets. Oxford: Elsevier.

Satoyoshi, K. and Mitsui, H. (2012). Option valuation under bulls and bears market conditions (Working papers series 12-01). Retrieved from https://www.eco.nihonu.ac.jp/center/economic/publication/pdf/12-01.pdf

Schaller, H. and Norden, S. V. (1997). Regime switching in stock market returns. Applied Financial Economics, 7(2), 177-191. https://doi.org/10.1080/096031097333745

Schwert, G. W. (1989). Why does stock market volatility change over time? The Journal of Finance, 44(5), 1115-1153. https://doi.org/10.1111/j.1540-6261.1989.tb02647.x

Sevüktekin, M. ve Nargeleçekenler, M. (2006). İstanbul Menkul Kıymetler Borsasında getiri volatilitesinin modellenmesi ve önraporlanması [Modeling and forecasting of return volatility at Istanbul Stock Exchange]. Ankara Üniversitesi SBF Dergisi, 61(4), 243-265. Retrieved from https://dergipark.org.tr/en/pub/ausbf/

Škrinjarić, T. and Šego, B. (2016). Asset allocation and regime switching on Croatian financial market. Croatian Operational Research Review, 7(2), 201-215. https://doi.org/10.17535/crorr.2016.0014

Şahin, Ö. (2016). Güniçi fiyat anomalisi'nin ARCH ailesi modelleri ile test edilmesi; Borsa İstanbul 100 ve kurumsal yönetim endeksi üzerine bir uygulama [Testing intra-day anomalies by ARCH family models; an application on BIST 100 and BIST corporate governance indexes]. Balıkesir Üniversitesi Sosyal Bilimler Enstitüsü Dergisi, 19(36), 329-360. Retrieved from https://dergipark.org.tr/en/pub/baunsobed/

Tu, J. (2010). Is regime switching in stock returns important in portfolio decisions?. Management Science, 56(7), 1198-1215. https://doi.org/10.1287/mnsc.1100.1181

Turner, C. M., Startz, R. and Nelson, C. R. (1989). A Markov model of heteroskedasticity, risk, and learning in the stock market. Journal of Financial Economics, 25(1), 3-22. https://doi.org/10.1016/0304-405X(89)90094-9 
A. Kaya \& İ. Y.Yarbaş1, "Forecasting of Volatility in Stock Exchange Markets By MS-GARCH Approach: An Application of Borsa Istanbul"

Ural, M. ve Adakale, T. (2009). Beklenen kayıp yöntemi ile riske maruz değer analizi [Value at risk analysis with expected shortfall]. Akdeniz I.I.B.F. Dergisi, 9(17), s. 23-39. Retrieved from https://dergipark.org.tr/en/pub/auiibfd

Visković, J., Arnerić, J. and Rozga, A. (2014). Volatility switching between two regimes. International Journal of Economics and Management Engineering, 8(3), 699-703. https://doi.org/10.5281/zenodo.1091336

Wang, P. and Theobald, M. (2008). Regime-switching volatility of six East Asian emerging markets. Research in International Business and Finance, 22(3), 267-283. https://doi.org/10.1016/j.ribaf.2007.07.001 